\title{
Otolith micro-increment formation in herring Clupea harengus larvae in relation to growth rate
}

\author{
Clive J. Fox ${ }^{1, *}$, Arild Folkvord ${ }^{2}$, Audrey J. Geffen ${ }^{3}$ \\ ${ }^{1}$ The Centre for Environment, Fisheries and Aquaculture Research, Lowestoft Laboratory, Pakefield Road, \\ Lowestoft NR33 0HT, Suffolk, UK \\ ${ }^{2}$ Department of Fisheries and Marine Biology, University of Bergen, 5020 Bergen, Norway \\ ${ }^{3}$ Port Erin Marine Laboratory, School of Biological Sciences, University of Liverpool, Port Erin IM9 6JA, \\ Isle of Man, British Isles
}

\begin{abstract}
Estimating the age of individual fish larvae using otolith micro-increments has become a widely used tool in early life-history ecology. A basic assumption of the method is that the microincrements are formed on a regular (usually daily) basis. Validation experiments are recommended to test this assumption, since otolith microstructure varies between species and interpretation of the structures can be problematic. Whilst many such experiments have demonstrated daily deposition rates, those examining slow-growing larvae have often not supported this assumption. In response, it has been suggested that increments are in fact being formed on a daily basis, but that they are too narrow to be resolved by optical microscopy. In this study, we raised herring larvae over a range of growth rates by manipulating prey levels. At 16 and $37 \mathrm{~d}$ old, the otoliths were marked by immersion of the larvae in a solution of alizarin complexone. The rearing experiment was terminated at $51 \mathrm{~d}$ post-hatch, and after suitable preparation, otoliths were examined using both light and scanning electron microscopy. Micro-increment counts based on light microscopy were lower than expected (assuming daily deposition) when larval growth rates were less than $0.42 \mathrm{~mm} \mathrm{~d}^{-1}$. These results are in accord with previous reports in the literature. Examination of the otolith region between the alizarin marks by scanning electron microscopy (SEM) produced slightly higher increment counts compared with light microscopy (average +2 ), but this was not sufficient to support the assumption of daily deposition of micro-increments between Days 16 and 37 in slow-growing larvae. Rather than leading to the regular deposition of narrow increments, slow growth in laboratory-reared herring larvae often appears to affect otolith structure. This results in fewer than the expected number of increments being deposited, and affects counts made both by light and scanning electron microscopy. Growth rates attained in this laboratory study are typical of those that may be experienced by cohorts of herring larvae in the wild, particularly from autumn spawning stocks. The use of otolith microstructure to estimate absolute ages of slow-growing herring larvae may therefore lead to significant underestimates of true age, even if SEM is used.
\end{abstract}

KEY WORDS: Otolith · Micro-increments · Deposition $\cdot$ Growth rate

\section{INTRODUCTION}

Over the last decade, analysis of otolith microstructure has become a widely applied tool in ecological studies of the early life history of fish. The technique relies upon the assumption that identifiable micro-increments in the otoliths are deposited on a regular (normally daily) basis and can thus be used to estimate the age of the indi- vidual. By combining this information with measures of larval size, it becomes possible to estimate ecologically important parameters, such as growth rates and birth date distributions (Campana 1992).

However, differences in otolith microstructure do occur between species and the interpretation of these structures is not always straightforward. It is therefore strongly recommended that validation experiments are 
undertaken before field material is examined. Such experiments with herring have found that increments apparently form at rates of less than $1 \mathrm{~d}^{-1}$ in slowgrowing larvae (Geffen 1982). This observation raised serious concerns over the application of otolith microincrement analysis for age determination in herring larvae. Morales-Nin (2000) suggested that inadequate nutrition during these experiments was responsible, but more recent trials by Folkvord et al. (2000) using larvae reared on natural zooplankton, which should be nutritionally adequate, have led to similar results.

An alternative explanation for apparent non-daily deposition rates was provided by Campana et al. (1987). In their hypothesis, non-daily deposition is explained by low somatic, and hence, low otolith growth rates leading to the formation of daily increments that are too fine to be resolved by light microscopy. Since Geffen (1982) and Folkvord et al. (2000) used light microscopy for increment enumeration, they may have been under-counting increments that were actually present in the otoliths of slow-growing larvae.

Whether we should always expect daily microincrement formation depends upon the metabolic mechanisms by which otoliths are formed. There are few such mechanistic studies, particularly in larvae, and models of otolith growth are still largely theoretical (Edeyer et al. 2000, Morales-Nin 2000, Payan et al. 2002). Such models usually assume that growth increments form as a consequence of fluctuations in the endolymph that favour or inhibit the precipitation of calcium carbonate on the otolith. These fluctuations are thought to become entrained to external environmental cues (such as light levels) early in life (Mugiya 1974, Mugiya et al. 1981, Wright et al. 1992, Edeyer et al. 2000). However, otolith growth is also controlled by the rate of synthesis of the protein matrix that offers the sites for mineralisation (Morales-Nin 2000, Tytler et al. 2002). Since the rate of protein synthesis in the otolith is linked to growth and metabolism, it is plausible that the formation of each micro-increment may take longer in slow-growing fish.

The purpose of the present study was to rear herring larvae at a range of growth rates and to study the deposition frequency of the otolith micro-increments using light and scanning electron microscopy (SEM). Since the resolving power of SEM is around $4 \mathrm{~nm}$, narrow increments laid down during periods of slow growth should be visible using this technique, even when they cannot be resolved by light microscopy.

\section{MATERIALS AND METHODS}

Rearing of herring larvae. Gametes were collected from mature Buchan stock herring and the fertilised eggs were incubated at $10^{\circ} \mathrm{C}$ at the Large Scale Facility,
University of Bergen. On the day following the start of hatching, 500 larvae were counted out into each of four, $500 \mathrm{l}$ green fibreglass, square tanks. These were located in a constant temperature room $\left(10^{\circ} \mathrm{C}\right)$ equipped with programmable fluorescent lighting (Lysstyr ${ }^{\circledR}$ system) set to mimic the autumn light regime (Folkvord et al. 2000). Each tank was continuously aerated to ensure water mixing occurred. Fifty litres were siphoned from the tank bottom every $3 \mathrm{~d}$ and replaced with fresh seawater. In addition, 21 of algae (Isochrysis and Rhodomonas spp.) were added daily to condition the water. From Day 3 onwards, larvae were fed natural zooplankton which were collected at the Marine Biological Station, Espegrend, using a continuous filter system (Unik Filter Systems). Initially, a size fraction of 90 to $250 \mu \mathrm{m}$ was collected but the upper limit was increased to $355 \mu \mathrm{m}$ at $30 \mathrm{~d}$ post-hatching and to $500 \mu \mathrm{m}$ at $45 \mathrm{~d}$ post-hatching. Two rearing tanks ( $\mathrm{H} 1$ and $\mathrm{H} 2$ ) were assigned to high prey concentration (1000 prey $\mathrm{l}^{-1}$ ) and two (L1 and L2) to low prey concentration (100 prey $\mathrm{l}^{-1}$ ). Zooplankton levels were assessed each morning by counting the number of edible prey items in 5 replicate 8 or $240 \mathrm{ml}$ samples taken from the highand low-prey rearing tanks, respectively, using a tubesampler. Sufficient stock zooplankton was then added to return prey densities to the levels stated above.

Herring larval growth rates were assessed weekly by randomly sampling 20 larvae from each tank using a glass beaker. After collection the larvae were anaesthetised with MS-222 (Argent) and individual livestandard lengths (distance from the tip of upper jaw to a perpendicular at the end of the notochord) recorded using an Olympus SZH10 microscope linked to an interactive image analysis system (PISCES, Perceptive Instruments). They were then rinsed in distilled water, flash frozen in liquid nitrogen, and freeze-dried. Dry weights were recorded using a Sartorius microbalance (Sartorius). Mortality rates were assessed daily by recording the numbers of dead larvae in the rearing tanks or in siphoned bottom water.

Marking of otoliths. On the evenings corresponding to 16 and $37 \mathrm{~d}$ post-hatch, the water levels in the tanks were lowered, and alizarin-complexone solution (Sigma Chemical) buffered with sodium hydroxide added to give a final alizarin concentration of $100 \mathrm{mg} \mathrm{l}^{-1}$ (Iglesias \& Rodriguez-Ojea 1997). The following morning, the alizarin was gently flushed from the rearing tanks by raising and lowering the water level several times. Normal rearing protocols were resumed by mid-day.

Preparation and examination of otoliths from larvae using light microscopy and SEM. Rearing was terminated on the morning of Day 51 post-hatch and all remaining larvae were collected and stored in $90 \%$ ethanol buffered with excess calcium carbonate. Later, the standard lengths of preserved larvae were mea- 
sured and converted to equivalent live lengths using the appropriate formula from Fox (1996). The sagittal otoliths were then extracted from 20 randomly chosen larvae per rearing tank using fine needles and a dissecting microscope equipped with polarised light. Each otolith was individually mounted on a cover-slip using an epoxy resin (Petropoxy 154, Palouse Petro Products). The otoliths were then ground to the core using graded aluminium oxide paper (Testbourne) and finally polished using an aluminium-oxide block (Evans Lapidary). Otoliths were then viewed using transmitted light and ultra-violet epifluorescence on a Leica DMR epifluorescence microscope equipped with a $100 \mathrm{~W}$ mercury burner. Measurements of otolith length and width, the size of the core and distance to each alizarin mark along the major axis were recorded. Increment counts were then undertaken in transmission mode using a $\times 100$ oil-immersion objective selecting samples in random order. One micro-increment was defined as the area from the beginning of one light (L) zone to the beginning of the next (Tanaka et al. 1981, Campana \& Neilson 1985, Secor et al. 1995). According to Brothers (1981), Wright et al. (1992) and Morales-Nin (2000), the L-zone is formed during the active feeding period. Since herring feed predominantly during daylight (Blaxter 1965, Bainbridge \& Forsyth 1971, Blaxter \& Hunter 1982, Fox et al. 1999), we expect the L-zone to be deposited during the day and the dark (D) zone at night (Fey 2002). Alizarin would therefore be expected to become concentrated in the calcium-carbonate rich L-zone formed during the day following overnight marking. Despite being rapidly flushed from the rearing tanks on the morning following treatment, the alizarin marks in the otoliths often spread over more than 1 increment. This may be the result of continued deposition of alizarin from the body tissues of the larvae, or the depth-of-field result of the optical microscope. We therefore assigned the period of immersion as the first L-zone showing strong fluorescence (moving from the otolith core to the otolith edge). Assuming daily deposition of increments, we would expect 21 increments between the first and second alizarin marks, and 12 increments from the second alizarin mark to the otolith edge (a complete increment would not form on the last day since larvae were removed from the rearing tanks around midday). Each otolith was initially read twice in random order by the principal author. Data were then compiled and where counts differed by more than 2 increments, the otolith re-examined to try and resolve the difference.

After examination by optical microscopy, each otolith was etched using $5 \%$ EDTA in preparation for viewing by $\mathrm{SEM}^{1}$. Etching times varied from $30 \mathrm{~s}$ to $2 \mathrm{~min}$. After rinsing in distilled water, samples were desiccated for at least $24 \mathrm{~h}$, mounted on SEM stubs, gold sputter-coated and examined using a Jeol 5200 (Jeol) scanning electron microscope. The positions on the SEM images corresponding to the alizarin marks were determined by overlaying digital images from the light microscope and SEM using Adobe Photoshop 9.0 (Adobe Systems). In most cases, alignment could be achieved using marks on the otolith surface after scaling of the images relative to calibrations made on the SEM and optical systems. Each SEM image was examined by each of the authors, and a consensus increment count for the regions between the core edge and first alizarin mark, and between the first and second alizarin marks, agreed.

\section{RESULTS}

\section{Rearing conditions}

Environmental conditions in the rearing tanks varied little throughout the experiment. Daily temperature averaged from $10.2 \pm 0.1$ to $10.4 \pm 0.1^{\circ} \mathrm{C}$ (mean $\pm \mathrm{SD}$ ) in the rearing tanks, and oxygen levels were generally above $87 \%$ saturation. Prey densities (average concentration before and after adjustment to nominal density) were $64 \pm 14$ and $1025 \pm 290$ prey items $l^{-1}$ in the low and high concentration groups, respectively.

\section{Larval survival and growth}

Herring larval mortality rates over the $51 \mathrm{~d}$ rearing period were low. A number of larvae in Tank L1 were damaged when alizarin was being flushed from the system during the initial marking. Excluding these, and correcting for larvae sampled, overall survival rates were $76 \%$ in $\mathrm{H} 1,82 \%$ in $\mathrm{H} 2,72 \%$ in $\mathrm{L} 1$ and $73 \%$ in L2. Applying ANOVA to the final measurements from Day 51 confirmed that the different feeding levels had a highly significant effect on the mean standard length and dry weight of each larval group $\left(F_{\text {length }}=36.1_{(76)}, \mathrm{p}<0.001 ; F_{\text {dry weight }}=32.6_{(76)}, \mathrm{p}<\right.$ 0.001). Tukey's post-hoc HSD indicated that after $51 \mathrm{~d}$ of rearing, larvae fed 1000 prey $\mathrm{l}^{-1}$ were, on average, significantly longer and heavier compared with lar-

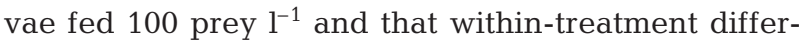
ences were not significant $(p>0.05)$. It is also worth noting that some individual larvae in the low prey treatment were as large as larvae in the high prey

\footnotetext{
${ }^{1}$ In addition to standard etching methods (5\% EDTA), we attempted proteinase-K etching as described by Shiao (1999) and imaging of polished, un-etched otoliths using backscatter detection (Waldron \& Gerneke 1997). However, these methods did not produce improved results.
} 


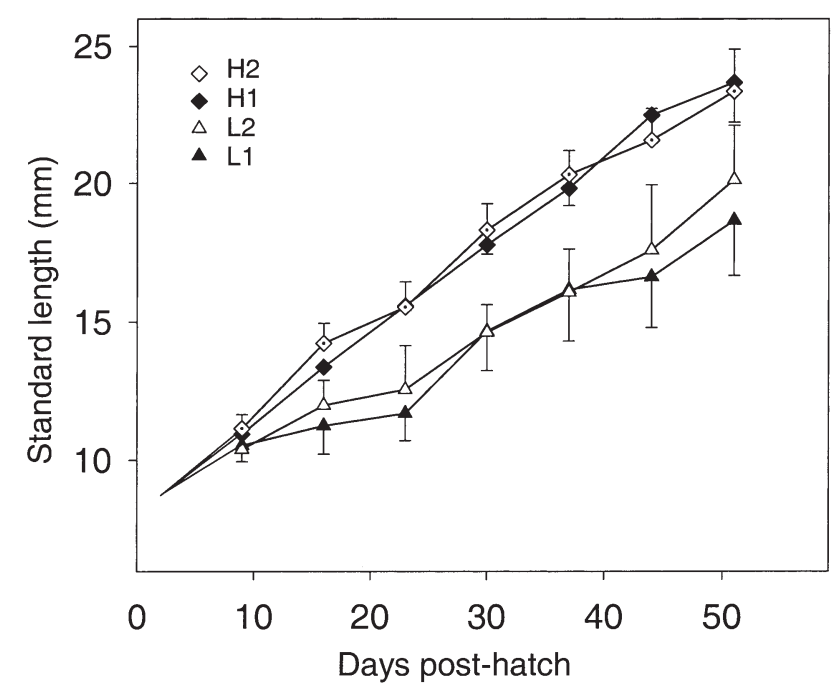

Fig. 1. Clupea harengus. Changes in larval standard length with time for each feeding treatment: $\mathrm{H} 1$ and $\mathrm{H} 2$ are tanks fed at 1000 prey $\mathrm{l}^{-1}$; L1 and L2 are tanks fed at 100 prey $\mathrm{l}^{-1}$.

Symbols indicate mean \pm SD $(n=20$ larvae per sample)
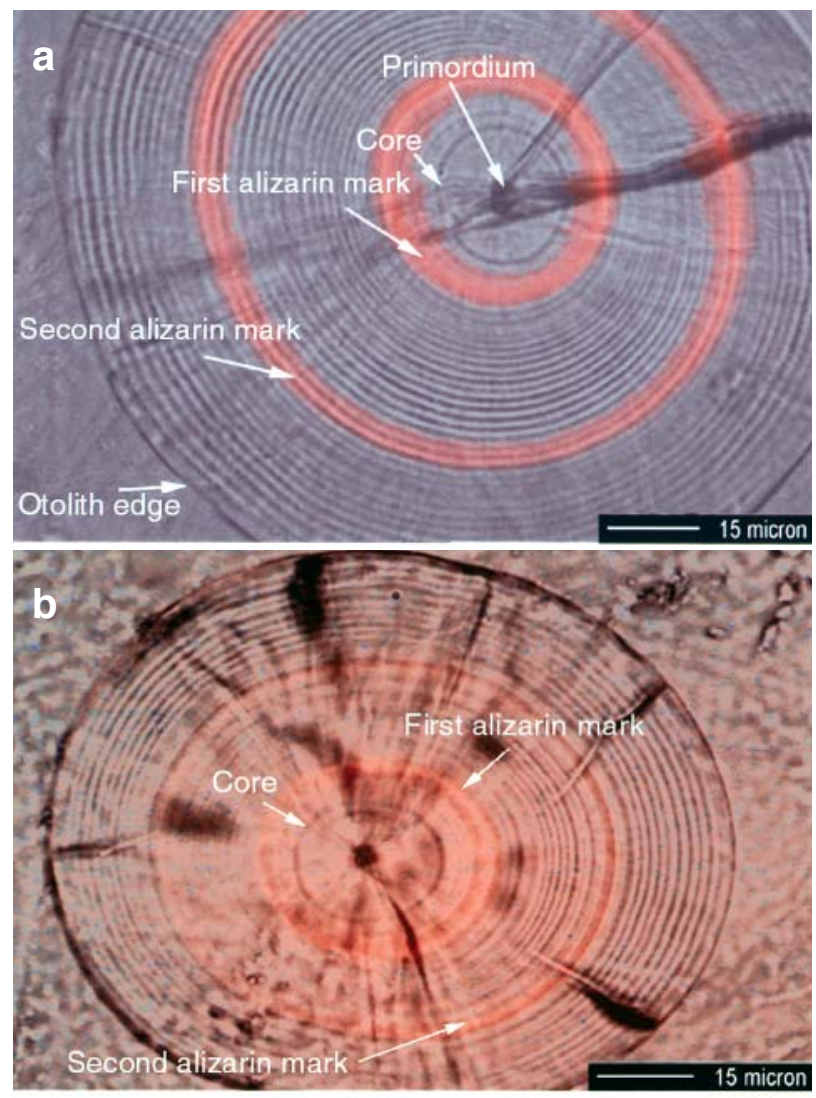

Fig. 2. Clupea harengus. Optical photomicrographs of sagittal otoliths from $51 \mathrm{~d}$ old herring larvae showing the visible features and the fluorescent alizarin marks. (a) Otolith from a $25.3 \mathrm{~mm}$ long larva from Tank H1; (b) otolith from a $19.8 \mathrm{~mm}$ long larva from Tank L1. Both images are overlaid composites of 2 original images using a $\times 63$ PLAN APO oil-immersion objective treatment at the end of the experiment (Fig. 1). In subsequent analyses, growth was treated as a continuous variable on the assumption that length-increases in individual larvae within each tank were linear.

\section{Light microscope analyses of otoliths from $51 \mathrm{~d}$ old larvae}

Otoliths from larger larvae had clear increments from close to the core boundary out to the otolith edge, with increment widths increasing steadily (Fig. 2a). In contrast, otoliths from smaller larvae often showed less welldefined increments of irregular widths (Fig. 2b). In extreme cases, no clear increments were visible (Fig. 3). In some otoliths, but not all, a check was apparent which coincided with the position of the alizarin mark (Fig. 4).

The average major-axis diameter of the core of left sagittae was $24.2 \pm 2.8 \mu \mathrm{m}(\mathrm{n}=42)$ and there was no detectable difference between core diameters of left and right sagittae ( $t$-test dependent samples, $t=$ $\left.0.61_{(28)}, p=0.54\right)$, nor was there any detectable effect of feeding level or tank on this parameter (ANOVA, $F=$ $\left.0.57_{(3,38),} \mathrm{p}=0.63\right)$. Based on these measurements, we assume that the core is equivalent to the hatch check described by Campana \& Moksness (1991), which was termed the first check by Høie et al. (1999). Similarly there were no detectable differences comparing the major axis diameter of left and right otoliths ( $t$-test dependent samples, $\left.t=0.54_{(72)}, \mathrm{p}=0.59\right)$. The alizarin treatment resulted in identifiable fluorescent marks in

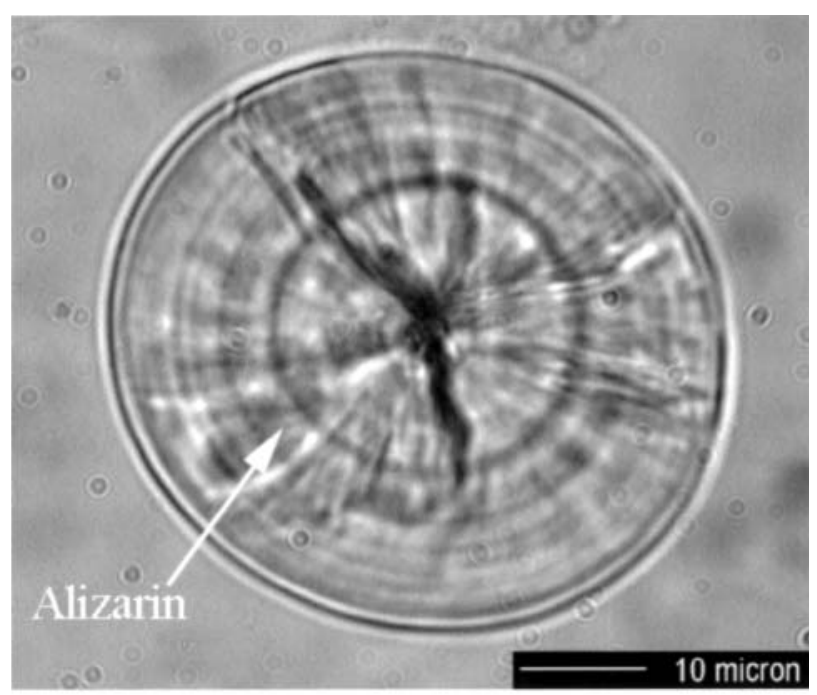

Fig. 3. Clupea harengus. Optical photomicrograph of sagittal otolith from a very slow-growing, $51 \mathrm{~d}$ old larva showing the lack of clear increments. The otolith is from a $14.6 \mathrm{~mm}$ long larva from Tank L1 viewed using a $\times 100$ PLAN APO oilimmersion objective; in this case, only a single faint alizarin band was visible (arrow) 


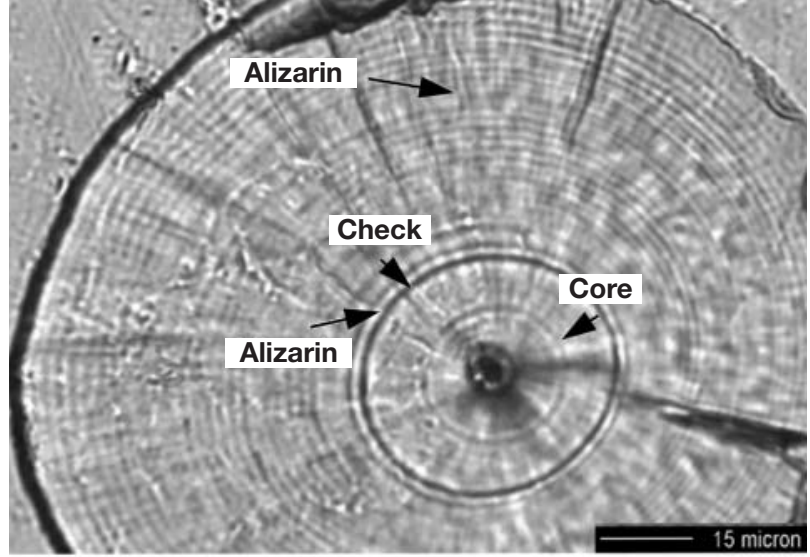

Fig. 4. Clupea harengus. Optical photomicrograph of sagittal otolith from a $51 \mathrm{~d}$ old herring larva showing a check coincident with first alizarin mark. The otolith is from a $23.8 \mathrm{~mm}$ long larva from Tank H1 viewed using a $\times 63$ PLAN APO oilimmersion objective

$>95 \%$ of sagittae examined, although the marks tended to be fainter in otoliths from smaller larvae.

There was no detectable difference in optical increment counts comparing left and right otoliths for counts between the core edge and first alizarin mark ( $t$-test dependent samples, $\left.t=0.71_{(64)}, \mathrm{p}=0.48\right)$, between the alizarin marks ( $t$-test dependent samples, $t=$ $\left.1.82_{(62),} \mathrm{p}=0.07\right)$, or from the second alizarin mark to the otolith edge ( $t$-test dependent samples, $t=0.36_{(64)}$, $p=0.72$ ). Further analyses therefore use either the counts on the right or left otolith.

Increment counts between the core edge and the first alizarin mark ranged from 0 to 8 (Fig. 5). There was a trend towards a greater number of increments

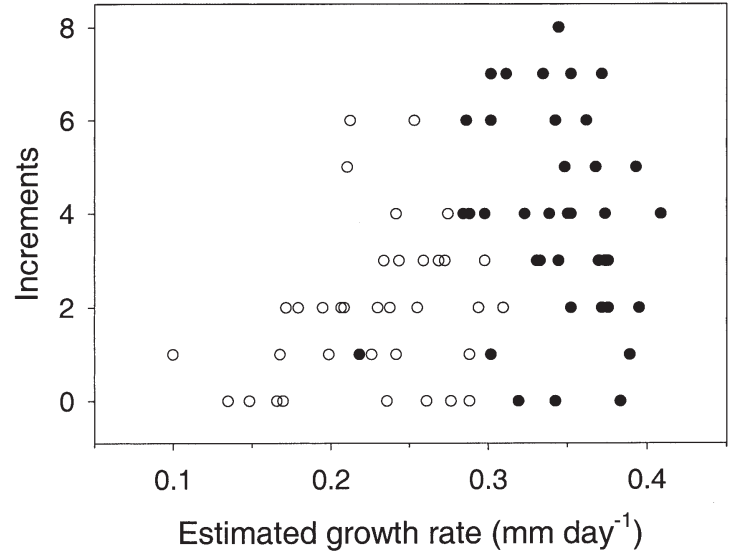

Fig. 5. Clupea harengus. Numbers of micro-increments determined by light microscopy between the edge of the core and the first alizarin mark for otoliths from $51 \mathrm{~d}$ old herring. (•) larvae reared at 1000 prey $\mathrm{l}^{-1}$; (०) larvae reared at 100 prey $\mathrm{l}^{-1}$

in this area in otoliths from larger larvae. Between the 2 alizarin marks there was a highly significant relationship $\left(F=160.0_{(1,74)}, \mathrm{p}<0.001\right)$ between the deposition rate of increments and larval growth rate (assuming a linear increase in individual length from hatching at an average length of $8.01 \pm 0.22 \mathrm{~mm}[\mathrm{n}=20]$ ). Even in individual larvae that had grown at the maximum growth rate in this study, average increment deposition rates in this region of the otolith were non-daily (Fig. 6a). A more constant rate of increment formation, which accorded with daily deposition, was observed in the area of the otolith deposited after the second alizarin marking (Days 37 to 51) for individual larvae with estimated growth rates higher than $0.25 \mathrm{~mm} \mathrm{~d}^{-1}$
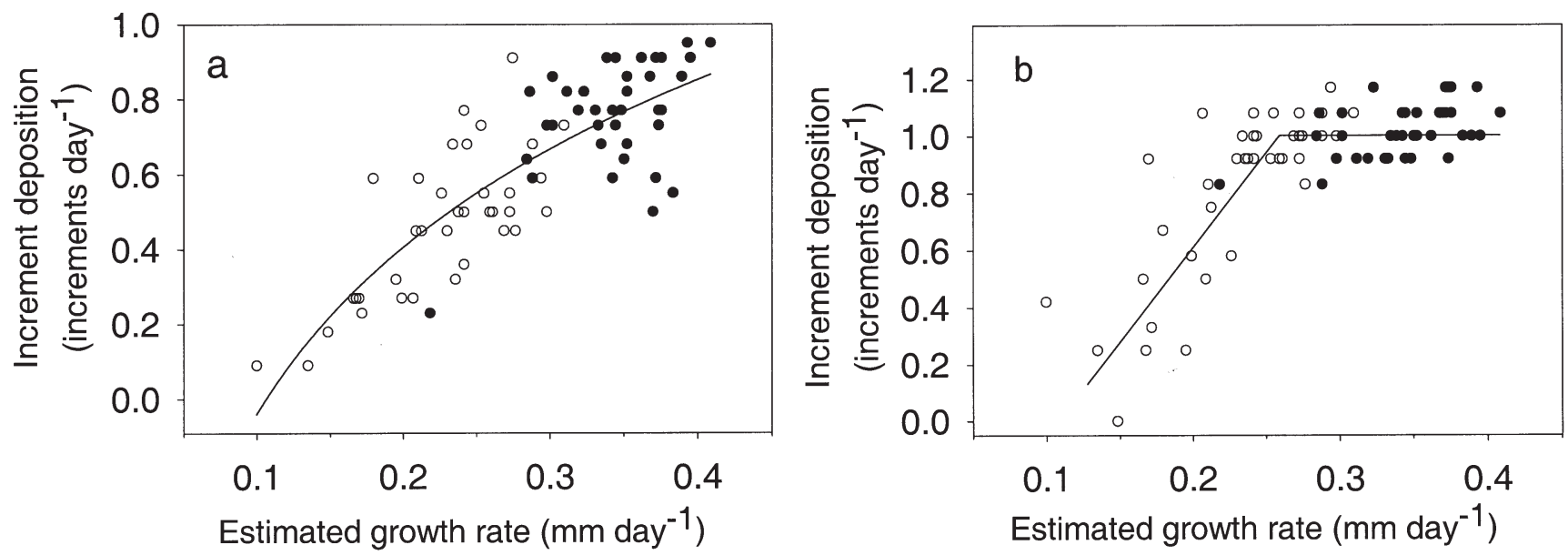

Fig. 6. Clupea harengus. Relationship between apparent micro-increment deposition rates determined by light microscopy and the estimated growth rates in terms of larval standard length. (•) larvae reared at 1000 prey $\mathrm{l}^{-1}$; (o) larvae reared at 100 prey $\mathrm{l}^{-1}$. Deposition rate of increments laid down (a) between the 2 alizarin marks, and (b) between the second alizarin mark and the outer edge of the otolith 


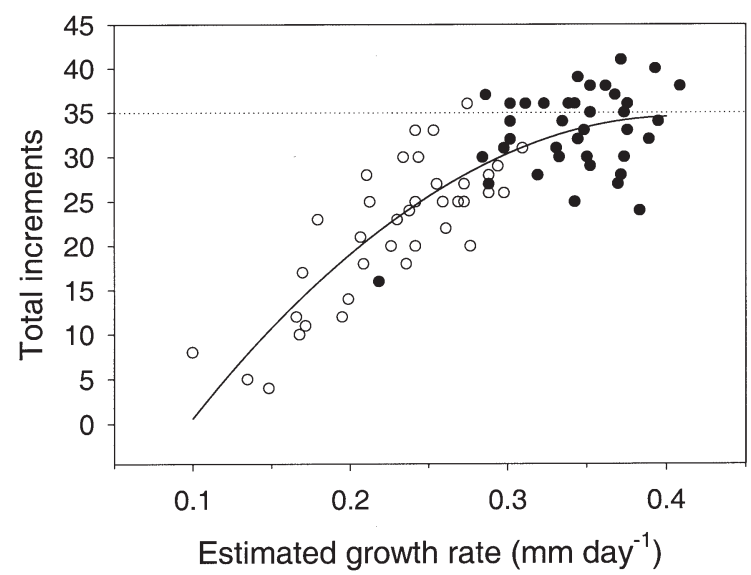

Fig. 7. Clupea harengus. Relationship between total increments, as determined by light microscopy, and estimated larval growth rates. Dotted line indicates the expected number of increments, assuming daily deposition and that the first increment is deposited at $16 \mathrm{~d}$ post-hatch

(Fig. 6b). If the whole otolith is considered, increment counts tended to stabilise when larval growth rates exceeded $0.42 \mathrm{~mm} \mathrm{~d}^{-1}$, but the scatter of data about the mean was up to \pm 10 increments (Fig. 7).

\section{SEM analyses}

The percentage of preparations yielding useable SEM images was low (approx. 22\%). Judgement of image quality is necessarily subjective, but we included criteria such as the presence of a clear microstructure and resolution of individual crystals.

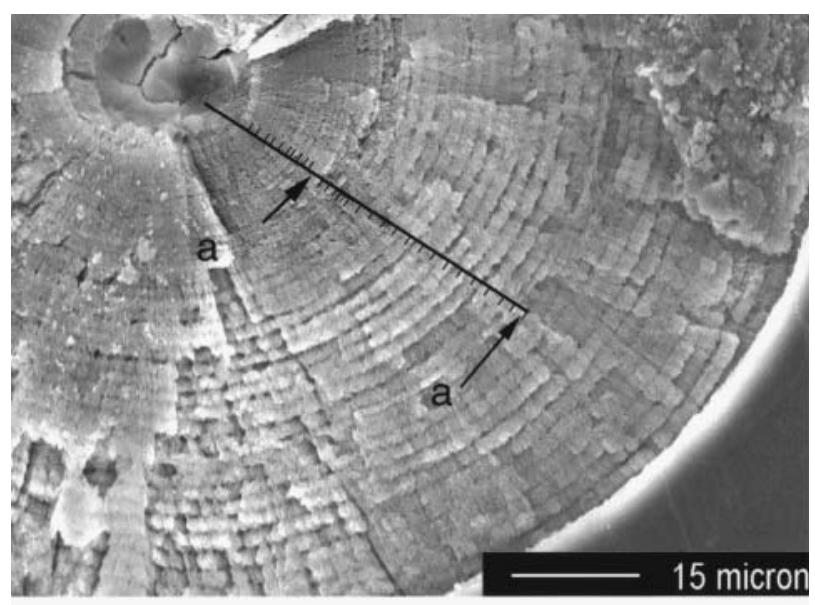

Fig. 8. Clupea harengus. Scanning electron photomicrograph of the sagittal otolith from $51 \mathrm{~d}$ old, $26.0 \mathrm{~mm}$ long larva from Tank H1 viewed at $\times 1000$ magnification. a: Positions coincident with the alizarin marks; ticks on radial line indicate positions of light (L) zones

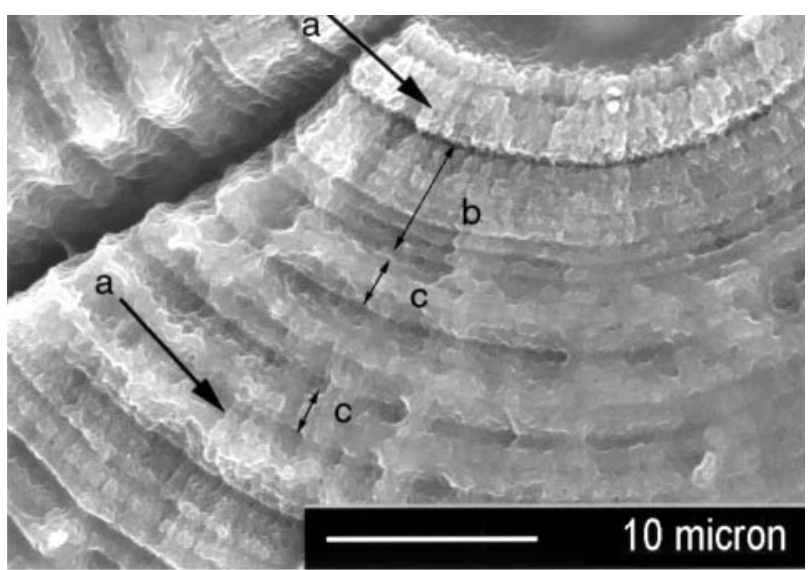

Fig. 9. Clupea harengus. Scanning electron photomicrograph of the sagittal otolith from $51 \mathrm{~d}$ old, $23.0 \mathrm{~mm}$ long larva from Tank L2 viewed at $\times 3500$ magnification. (a) Positions coincident with the alizarin marks; (b) area of regular increments; (c) broad increment, possibly formed by partial merging of several increments

Otoliths from larger larvae were easier to prepare and usually showed regular increments (Fig. 8). In contrast, otoliths from smaller larvae often showed areas of broad increments. In some cases these appeared to be composed of partially merged finer increments (Fig. 9). In otoliths from extremely small larvae, there were few

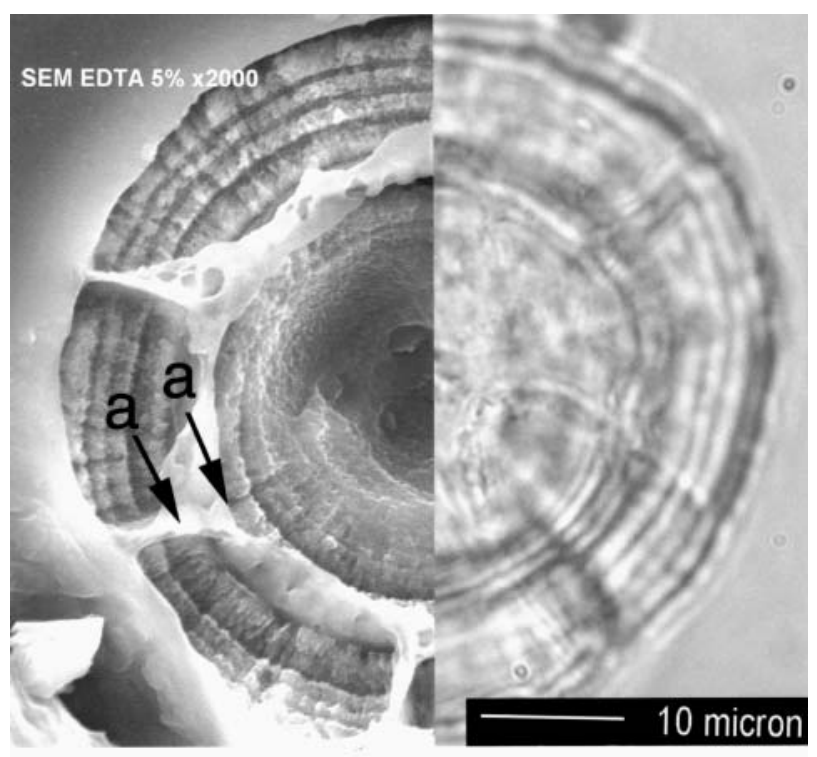

Fig. 10. Clupea harengus. Scanning electron photomicrograph of the sagittal otolith from $51 \mathrm{~d}$ old, slow growing, $12.9 \mathrm{~mm}$ long larva from Tank L1. Left-hand side is $\times 2000$ magnification scanning electron microscopy (SEM). a: Positions coincident with the alizarin marks. Right-hand side is light microscopy image viewed using $\times 100$ PLAN APO oilimmersion objective 


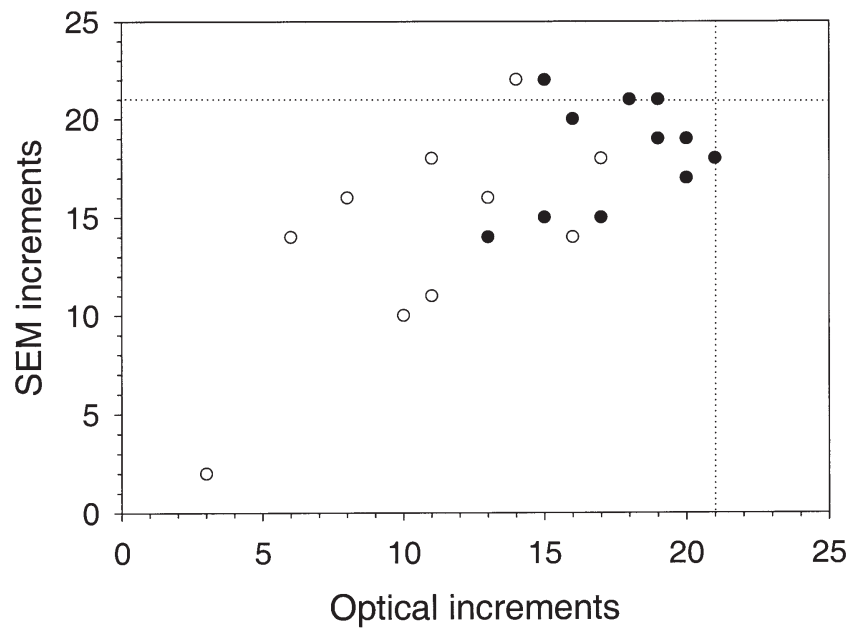

Fig. 11. Clupea harengus. Comparison of the number of increments between the alizarin marks determined from scanning electron microscopy (SEM) images and the number of increments counted using light microscopy from individual sagittae. Solid circles represent: sagittae from larvae reared at

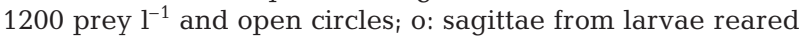
at 100 prey $\mathrm{l}^{-1}$; the dashed lines are the expected number of increments assuming daily deposition.

clear increments, even outside of the second alizarin marking (Fig. 10). Increment counts based on SEM were significantly higher than from light microscopy (Wilcoxon sign rank test $_{(24)}, \mathrm{p}=0.033$ ), but the average difference was +2 and counts based on SEM still rarely reached the expected level of 21 increments between the alizarin marks, particularly in slow-growing larvae (Fig. 11).

\section{DISCUSSION}

In recent years, otolith microstructure has been widely used to determine larval age, and thus, estimate parameters such as growth rates and survivor hatch-dates. The underlying assumption of the technique is that identifiable structures in the otolith are produced on a daily basis. Because of difficulties in differentiating daily and non-daily increments, it is advisable to carry out validation studies before the technique is applied to field-caught material. A variety of validation methods are available and are described by Geffen (1987, 1992).

Using such methods, Campana \& Moksness (1991) and Moksness (1992) reported successful validation of micro-increment formation in Norwegian springspawned herring larvae reared in mesocosms. However, larvae in both these studies were growing at reasonably high rates of ca. $0.37 \mathrm{~mm} \mathrm{~d}^{-1}$ (recalculated from figures in the cited papers for a period of 16 to
$51 \mathrm{~d}$ post-hatch). In addition, the latter study revealed a large reader-dependent variation in increment counts, implying difficulty in the interpretation of the microstructures. Daily increment deposition has also been reported for 2 cohorts of field-caught Pacific herring larvae by McGurk (1987), but non-daily formation was observed in a third cohort whose growth was coincident with a period of low water temperature.

A number of publications have reported apparent increment deposition rates of less than $1 \mathrm{~d}^{-1}$ in herring larvae, a phenomenon often associated with low growth rates (Table 1). Using laboratory- and mesocosm-reared material, Geffen (1982) reported that the rates of increment formation were related to larval growth rates. Daily deposition only occurred if larval growth rates exceeded $0.4 \mathrm{~mm} \mathrm{~d}^{-1}$. Similar results have since been reported by McGurk (1983) and Folkvord et al. (2000). Results from these studies have been criticised on the grounds that the otoliths were not ground and polished before examination (Campana \& Neilson 1985). However, our results using ground and polished otoliths appear fully consistent with those previously reported by Geffen (1982), McGurk (1983), Folkvord et al. (2000) and Feet et al. (2002).

The occurrence of non-daily increment deposition in otoliths does appear to be species-specific (Table 1). Those species with relatively slow-growing larvae and long yolk-sac periods appear to present particular problems (Campana et al. 1987, Jones \& Brothers 1987). In contrast, increment deposition rates in larval cod Gadus morhua appeared to be daily, even under reduced growth conditions (Geffen 1995).

\section{Otolith increment analyses - light microscopy}

The problem of reconciling optical increment counts with known age can be split into 2 parts. Firstly, the period when growth is dependent upon yolk reserves, and secondly, during post yolk-sac growth. In the first period, increment formation may be free-running before becoming entrained to daily signals related to patterns in feeding and metabolism (Geffen 1982, Morales-Nin 2000). Lough et al. (1982) reported that the first 3 increments in larval herring were not deposited daily and that their formation spanned a period of 8 to $10 \mathrm{~d}$ post-hatch. The formation of the first clear increment in herring larvae is thought to coincide with the onset of feeding, around the completion of yolk-sac absorption (Geffen 1982, Høie et al. 1999). Assuming subsequent daily increment formation, it has become common practice to add a constant number of days to optical increment counts to estimate true age (for example, the addition of $10 \mathrm{~d}$ for Norwegian spring-spawned herring, Moksness 1992; 12 d for 
Table 1. Effects of slow growth on micro-increment formation rates in the otoliths of larval fish. SEM: scanning electron microscopy

\begin{tabular}{|c|c|c|c|c|c|}
\hline Source & Species & $\begin{array}{l}\text { Rearing } \\
\text { condition }\end{array}$ & $\begin{array}{l}\text { Independent } \\
\text { age criteria }\end{array}$ & $\begin{array}{l}\text { Observation } \\
\text { method }\end{array}$ & Observations of rate of increment formation \\
\hline $\begin{array}{l}\text { Laroche et al. } \\
(1982)\end{array}$ & Parophrys vetulus & Laboratory & Known age & Optical & Non-daily in proportion to larval size \\
\hline Geffen (1982) & Clupea harengus & $\begin{array}{l}\text { Laboratory and } \\
\text { mesocosm }\end{array}$ & Known age & Optical & Non-daily in larvae growing at $<0.4 \mathrm{~mm} \mathrm{~d}^{-1}$ \\
\hline Geffen (1982) & $\begin{array}{l}\text { Scophthalmus } \\
\text { maximus }\end{array}$ & Laboratory & Known age & Optical & Non-daily in larvae growing at $<0.3 \mathrm{~mm} \mathrm{~d}^{-1}$ \\
\hline McGurk (1983) & $\begin{array}{l}\text { Clupea harengus } \\
\text { pallasi }\end{array}$ & Laboratory & Known age & Optical & Non-daily in larvae growing at $<0.4 \mathrm{~mm} \mathrm{~d}^{-1}$ \\
\hline McGurk (1987) & $\begin{array}{l}\text { Clupea harengus } \\
\text { pallasi }\end{array}$ & Field sampled & $\begin{array}{l}\text { Length-frequency } \\
\text { analysis }\end{array}$ & Optical & $\begin{array}{l}\text { Non-daily in third cohort of larvae } \\
\text { coincident with period of low water } \\
\text { temperature }\end{array}$ \\
\hline $\begin{array}{l}\text { Jones \& } \\
\text { Brothers (1987) }\end{array}$ & Morone saxatilis & Laboratory & Known age & $\begin{array}{l}\text { Optical } \\
\text { SEM }\end{array}$ & $\begin{array}{l}\text { Non-daily during periods of starvation; } \\
\text { fine increments visible using SEM }\end{array}$ \\
\hline $\begin{array}{l}\text { Bailey \& Stehr } \\
\text { (1988) }\end{array}$ & $\begin{array}{l}\text { Theragra } \\
\text { chalcogramma }\end{array}$ & Laboratory & Known age & Optical & Non-daily in larvae fed low ration \\
\hline $\begin{array}{l}\text { Lagardere } \\
(1989)\end{array}$ & Solea solea & Laboratory & Known age & Optical & $\begin{array}{l}\text { Low-contrast increments formed when } \\
\text { starved for up to } 5 \mathrm{~d} \text {, but deposition rate no } \\
\text { significantly different from } 1 \mathrm{~d}^{-1}\end{array}$ \\
\hline $\begin{array}{l}\text { Szedlmayer \& } \\
\text { Able (1992) }\end{array}$ & $\begin{array}{l}\text { Paralichthys } \\
\text { dentatus }\end{array}$ & Laboratory & Known age & $\begin{array}{l}\text { Optical } \\
\text { SEM }\end{array}$ & $\begin{array}{l}\text { Non-daily during first } 47 \mathrm{~d} \text { post-hatch when } \\
\text { growth rate was around } 0.1 \mathrm{~mm} \mathrm{~d}^{-1} \text {; no } \\
\text { significant difference between optical and } \\
\text { SEM increment counts }(\mathrm{n}=20)\end{array}$ \\
\hline Casas (1998) & $\begin{array}{l}\text { Pleuronectes } \\
\text { americanus }\end{array}$ & Mesocosm & Known age & Optical & $\begin{array}{l}\text { Non-daily in slow-growing larvae in cold } \\
\text { water }\end{array}$ \\
\hline $\begin{array}{l}\text { Folkvord et al. } \\
(2000)\end{array}$ & Clupea harengus & Laboratory & Known age & Optical & $\begin{array}{l}\text { Non-daily in periods of slow growth due to } \\
\text { restricted feeding }\end{array}$ \\
\hline Feet et al. (2002) & Clupea harengus & Mesocosm & Known age & Optical & $\begin{array}{l}\text { Non-daily in slow growing, spring spawned } \\
\text { larvae reared under low prey densities }\end{array}$ \\
\hline
\end{tabular}

Baltic herring, Arrhenius \& Hansson 1996; and $19 \mathrm{~d}$ for Georges Bank herring, Bolz \& Burns 1996). Whilst this may increase the accuracy of age estimates, it will not necessarily improve precision, since there is likely to be variability in the timing of the onset of feeding between individual larvae (Blaxter \& Hempel 1966). Indeed, the present study showed that by the time yolk-sac absorption was completed (16 d post-hatch), the otoliths contained a variable number of increments (from 0 to 8), with a tendency for higher numbers of increments to be present in larvae reared at higher prey densities (as demonstrated by counts between the core edge and the first alizarin mark). This suggests that early feeding success has a rapid impact on somatic and otolith growth and influences the timing of formation of the first increment.

Geffen (1982) suggested that it might be possible to distinguish increments formed prior to yolk-sac absorption from those formed after this event, and that a heavy check could be identified corresponding to the completion of yolk-sac absorption. Unfortunately we could not unambiguously identify such a check in the majority of otoliths from the present experiment. In some otoliths, a check was apparent which coincided with the first alizarin mark, but it was not possible to say whether this was related to the completion of yolk-sac absorption or caused by a temporary reduction in growth due to the alizarin immersion.

In the period following yolk-sac absorption, optically determined micro-increment deposition rates were clearly related to growth rates. Daily rates of deposition over the whole study period were predicted only for larvae growing above $0.42 \mathrm{~mm} \mathrm{~d}^{-1}$, a critical point which is in good agreement with Geffen (1982) and Folkvord et al. (2000). These findings are, of course, only of importance to field studies if growth rates lower than this occur in the wild. Although average cohort growth rates in the wild do not precisely reflect individual growth rates (because of size-selective mortality and individual variability), published data do indicate that growth rates of less than $0.2 \mathrm{~mm} \mathrm{~d}^{-1}$ are not uncommon, particularly for autumn-spawned herring larvae (Table 2). 
Table 2. Clupea harengus. Growth rates for post yolk-sac herring larvae from field studies. Studies using otolith micro-increment ageing were excluded, cited growth rates are from length-frequency analyses. Analysis method may vary with source (some studies analysed modal lengths, others mean lengths, etc.)

\begin{tabular}{|c|c|c|c|c|c|}
\hline Source & Location & $\begin{array}{l}\text { Spawning } \\
\text { season }\end{array}$ & $\begin{array}{l}\text { Growth rate } \\
(\mathrm{mm} \mathrm{d}-1)\end{array}$ & $\begin{array}{l}\text { Age } \\
\text { (d post-hatch) }\end{array}$ & Notes \\
\hline Marshall et al. (1937) & Clyde, Scotland & Spring & 0.43 & $10-80$ & - \\
\hline Henderson et al. (1984) & $\begin{array}{l}\text { Blackwater Estuary, } \\
\text { Essex, UK }\end{array}$ & Spring & 0.43 & $28-50$ & Growth was slower for yolk-sac larvae \\
\hline Jean (1956) & $\begin{array}{l}\text { Bay of Chaleur, } \\
\text { Québec }\end{array}$ & Spring & 0.43 & $10-70$ & $\begin{array}{l}\text { Based on maximum size of larvae at } \\
\text { each sampling }\end{array}$ \\
\hline Bowers (1952) & Irish Sea & Autumn & 0.16 & $23-210$ & $\begin{array}{l}\text { Evidence of slower growth over } \\
\text { winter months }\end{array}$ \\
\hline Jean (1956) & $\begin{array}{l}\text { Bay of Chaleur, } \\
\text { Québec }\end{array}$ & Autumn & 0.17 & $40-200$ & $\begin{array}{l}\text { Based on maximum size of larvae at } \\
\text { each sampling }\end{array}$ \\
\hline Tibbo et al. (1958) & $\begin{array}{l}\text { Georges Bank, } \\
\text { Gulf of Maine }\end{array}$ & Autumn & 0.23 & $30-160$ & $\begin{array}{l}\text { Evidence of slower growth in winter, } \\
\text { quoted rate estimated from Fig. } 8 \text { in } \\
\text { Tibbo et al. (1958), assuming linear } \\
\text { growth }\end{array}$ \\
\hline $\begin{array}{l}\text { Das (1968) } \\
\text { Das (1972) }\end{array}$ & Bay of Fundy & Autumn & 0.14 & $0-305$ & $\begin{array}{l}\text { Growth slowed in winter, quoted } \\
\text { values estimated from Fig. } 25 \text { in } \\
\text { Das (1968), assuming linear growth; } \\
\text { same data are presented in Das (1972) }\end{array}$ \\
\hline Sameoto (1972) & $\begin{array}{l}\text { Nova Scotian } \\
\text { coast }\end{array}$ & Autumn & 0.14 & $0-247$ & $\begin{array}{l}\text { Growth slightly non-linear, quoted } \\
\text { rates refitted to data from Fig. } 3 \text { in } \\
\text { Sameoto (1972), assuming linear } \\
\text { growth }\end{array}$ \\
\hline Boyar et al. (1973) & $\begin{array}{l}\text { Georges Bank, } \\
\text { Gulf of Maine }\end{array}$ & Autumn & 0.14 & $<215$ & $\begin{array}{l}\text { Growth rate estimated from Fig. } 7 \text { in } \\
\text { Boyar et al. (1973) }\end{array}$ \\
\hline Wood \& Burd (1976) & Central North Sea & Autumn & $0.16-0.24$ & $0-50$ & - \\
\hline Nichols et al. (1985) & Central North Sea & Autumn & $0.13-0.24$ & Not reported & $\begin{array}{l}\text { Quoted lengths suggest larvae were } \\
\text { at post yolk-sac stage }\end{array}$ \\
\hline $\begin{array}{l}\text { Graham \& Townsend } \\
\text { (1985) }\end{array}$ & $\begin{array}{l}\text { Sullivan Harbour, } \\
\text { Maine }\end{array}$ & Autumn & 0.18 & $60-90$ & $\begin{array}{l}\text { Growth rate estimated from increase } \\
\text { in cohort length mode }\end{array}$ \\
\hline $\begin{array}{l}\text { Graham \& Townsend } \\
\text { (1985) }\end{array}$ & $\begin{array}{l}\text { Sheepscot Estuary, } \\
\text { Maine }\end{array}$ & Autumn & 0.36 & $60-90$ & $\begin{array}{l}\text { Growth rate estimated from increase } \\
\text { in cohort length mode }\end{array}$ \\
\hline Munk et al. (1986) & NW North Sea & Autumn & $0.14-0.25$ & Not reported & - \\
\hline Heath \& Rankine (1988) & Northern North Sea & Autumn & $0.23-0.35$ & $9-14$ & Both cohorts at post yolk-sac stage \\
\hline $\begin{array}{l}\text { Munk \& Christensen } \\
\text { (1990) }\end{array}$ & Central North Sea & Autumn & $0.13-0.37$ & $<180$ & Includes larvae and juveniles \\
\hline
\end{tabular}

\section{Otolith increment analyses - SEM}

Results showing fewer than expected increments in known age samples can be reconciled with a daily deposition rate if one assumes that the increments are actually present but are too narrow to be resolved with the light microscope (Campana et al. 1987). Theoretical considerations suggest that resolution limits for standard optical microscopy will be around $0.3 \mu \mathrm{m}$. However, using SEM (with a resolution limit of ca. $4 \mathrm{~nm}$ ) we were unable to produce strong support for this argument. Although increment counts from SEM images were slightly higher than optical counts, we could not identify enough 'missing' increments in the otoliths of slow-growing larvae. Rather than simply affecting increment width alone, reduced growth rates appeared to lead to changes in otolith structure. In some cases, increments became merged to form solid calcium-carbonate-rich zones which appear as raised areas in EDTA-etched otoliths (Jones \& Brothers 1987), whilst in very slow-growing larvae, regular increment formation appeared to become completely disrupted. It has been suggested that the presence of a disrupted crystal structure and irregular or narrow $(<1 \mu \mathrm{m})$ increments could be used to identify slow-growing larvae in field samples (Folkvord et al. 2000, Feet et al. 2002). However, discarding these individuals will potentially bias population estimates of age, growth and mortality, and it is not always possible to unequivocally identify otoliths of slow-growing larvae from their appearance. 
In the present study, we decided to examine increment deposition between 2 known age-marks since it is often difficult to obtain a perfectly flat section from the core right out to the otolith edge (necessary for SEM), and the timing of deposition of the first increment is uncertain (Neilson 1992). Our approach could be criticised on 2 counts. Firstly, the process of alizarin marking may itself be stressful to the larvae and generate checks in the otolith (Geffen 1987). Our observations suggest that this probably did occur in some of the larvae as a result of reduced feeding success whilst the alizarin was being flushed from the rearing tanks. Secondly, our method requires accurate alignment of the SEM image with alizarin marks from a separate optical image. We acknowledge that this process may have introduced some uncertainty into the SEM increment counts, especially as the fluorescence from the alizarin was not confined to a single incremental zone. Incorporation of a chemical directly visible by SEM would reduce the amount of image manipulation required. Although statoliths of squid Illex illecebrosus and otoliths of salmon fry Oncorhynchus keta have been successfully marked using strontium, which can be detected by back-scatter SEM (Hurley et al. 1984, Schroder et al. 1994), it remains unclear whether sufficient strontium can be introduced into the otoliths of small fish larvae (Campana \& Neilson 1985).

In order to improve the statistical analysis, we would have liked to achieve a much higher success rate with SEM preparation, particularly of the smaller otoliths from slow-growing larvae. Several workers have commented on the time-consuming nature of otolith preparation for SEM, and the generally low success rates achieved (Campana et al. 1987, Jones \& Brothers 1987, Bailey \& Stehr 1988, Waldron \& Gerneke 1997). Few studies have managed to produce sufficient SEM images to allow any statistical comparison with counts from light microscopy (although see Szedlmayer \& Able 1992) and any technical advances to improve preparation of larval otoliths for SEM would greatly facilitate future validation studies.

As a final caution, it has been reported that microincrements in otoliths from laboratory-reared larvae may be fainter and less regular than those from wildcaught specimens (Brothers 1981, Campana \& Neilson 1985, Campana \& Moksness 1991). It has been suggested that this is caused by a lack of diurnal temperature fluctuations in most laboratory-based rearing experiments. Given the importance of the otolith microincrement technique in early life-history studies, the next step should be to test the present results using herring larvae reared under more natural conditions, for example in outdoor mesocosms.

\section{CONCLUSION}

Analysis of ground and polished otoliths from herring larvae using light microscopy demonstrated nondaily rates of micro-increment formation in larvae growing at less than $0.42 \mathrm{~mm} \mathrm{~d}^{-1}$ in the period from hatch to $51 \mathrm{~d}$ old, and in those growing at less than $0.25 \mathrm{~mm} \mathrm{~d}^{-1}$ from Day 37 to 51 . Examination of the otoliths by SEM failed to provide convincing evidence that this was due to the deposition of increments that were too fine to be resolved by light microscopy. Rather, the SEM results suggested that the crystal structure often becomes irregular and that the incremental structure is disrupted in otoliths from slow-growing, laboratory-reared larvae. Growth rates of larvae showing non-daily increment formation in the present study were within the range of lengthbased growth estimates from autumn-spawned herring larvae in the wild. These results imply that the use of otolith micro-increment counts to estimate the age of slow-growing herring larvae may lead to considerable under-estimates of true age, even if SEM is used.

Acknowledgements. This work was funded jointly by Defra (formerly MAFF) under program MF0420, Physical and Biological Controls on Fish Stocks, and the EU through the TMR (Training and Mobility of Researchers) Program, Grant ERBFMGECT950013. The authors wish to thank Dr. P. Tytler for supplying the herring gonads used in this trial, to Gary Jones, Hans Høie and Frank Midøy for technical assistance. All procedures used in this study complied with the current animal welfare regulations in Norway.

\section{LITERATURE CITED}

Arrhenius F, Hansson S (1996) Growth and seasonal changes in energy content of young Baltic Sea herring (Clupea harengus). J Mar Sci 53:792-801

Bailey KM, Stehr CL (1988) The effects of feeding periodicity and ration on the rate of increment formation in otoliths of larval walleye pollack Theragra chalcogramma (Pallas). J Exp Mar Biol Ecol 122:147-161

Bainbridge V, Forsyth DCT (1971) The feeding of herring larvae in the Clyde. Rapp P-v Réun Cons Int Explor Mer 160: $104-113$

Blaxter JHS (1965) The feeding of herring larvae and their ecology in relation to feeding. CALCOFI, California Cooperative Oceanic Fisheries Investigations 10:79-88

Blaxter JHS, Hempel G (1966) Utilization of yolk by herring larvae. J Mar Biol Assoc (UK) 46:219-234

Blaxter JHS, Hunter JR (1982) The biology of the clupeoid fishes. Adv Mar Biol 20:1-223

Bolz GR, Burns BR (1996) Age and growth of larval Atlantic herring, Clupea harengus: a comparitive study. Fish Bull 94:387-397

Bowers AB (1952) Studies on the herring (Clupea harengus L.) in Manx waters: the autumn spawning, and the larval and post-larval stages. Proc Trans Liverpool Biol Soc 58:47-74

Boyar HC, Marak RR, Perkins FE, Clifford RA (1973) Seasonal 
distribution and growth of larval herring (Clupea harengus L.) in the Georges Bank-Gulf of Main area from 1962 to 1970. J Cons Int Explor Mer 35:36-51

Brothers EB (1981) What can otolith microstructure tell us about daily and subdaily events in the early life history of fish. Rapp P-v Réun Cons Int Explor Mer 178:393-394

Campana SE (1992) Analysis of otolith microstructure data. Can J Fish Aquat Sci (Spec Publ) 117:73-100

Campana SE, Moksness E (1991) Accuracy and precision of age and hatch date estimates from otolith microstructure examination. J Mar Sci 48:303-316

Campana SE, Neilson JD (1985) Microstructure of fish otoliths. Can J Fish Aquat Sci 42:1014-1032

Campana SE, Gagne JA, Munro J (1987) Otolith microstructure of larval herring (Clupea harengus): image or reality? Can J Fish Aquat Sci 44:1922-1929

Casas MC (1998) Increment formation in otoliths of slowgrowing winter flounder (Pleuronectes americanus) larvae in cold water. Can J Fish Aquat Sci 55:162-169

Das N (1968) Spawning, distribution, survival, and growth of larval herring (Clupea harengus L.) in relation to hydrographic conditions in the Bay of Fundy. Report No. 88. Fisheries Research Board of Canada, Biological Station, St. Andrews, New Brunswick

Das N (1972) Growth of larval herring (Clupea harengus) in the Bay of Fundy and Gulf of Maine area. J Fish Res Bd Can 29:573-575

Edeyer A, Pontual Hd, Payan P, Troadec H, Sévère A, MayerGostan N (2000) Daily variations of the saccular endolymph and plasma compositions in the turbot Psetta maxima: relationship with the diurnal rhythm in otolith formation. Mar Ecol Prog Ser 192:287-294

Feet PØ, Ugland KI, Moksness E (2002) Accuracy of age estimates in spring spawning herring (Clupea harengus L.) reared under different prey densities. Fish Res 56: 59-67

Fey D (2002) Formation of daily increments in otoliths of larval and juvenile herring (Clupea harengus L.) and early juvenile smelt (Osmerus eperlanus L.) in low-food conditions. Arch Fish Mar Res 49:189-197

Folkvord A, Blom G, Johannessen A, Moksness E (2000) Growth-dependent age estimation in herring (Clupea harengus L.) larvae. Fish Res 46:91-103

Fox CJ (1996) Length changes in herring (Clupea harengus) larvae: effects of capture and storage in formaldehyde and alcohol. J Plankton Res 18:483-493

Fox CJ, Harrop R, Winpenny A (1999) Feeding ecology of herring (Clupea harengus) larvae in the turbid Blackwater estuary. Mar Biol 134:355-365

Geffen AJ (1982) Otolith ring deposition in relation to growth rate in herring (Clupea harengus) and turbot (Scophthalmus maximus) larvae. Mar Biol 71:317-326

Geffen AJ (1987) Methods of validating daily increment deposition in otoliths of larval fish. In: Summerfelt RC, Hall GE (eds) The age and growth of fish. Iowa State University, p 223-240

Geffen AJ (1992) Validation of otolith increment deposition rate. Can J Fish Aquat Sci (Spec Publ) 117:101-113

Geffen AJ (1995) Growth and otolith microstructure of cod (Gadus morhua L.) larvae. J Plankton Res 17:783-800

Graham JJ, Townsend DW (1985) Mortality, growth, and transport of larval Atlantic herring Clupea harengus in Maine coastal waters. Trans Am Fish Soc 114:490-498

Heath M, Rankine P (1988) Growth and advection of larval herring (Clupea harengus L.) in the vicinity of the Orkney Isles. Estuar Coastal Shelf Sci 27:547-565

Henderson PA, Whitehouse JW, Cartwright GH (1984) The growth and mortality of larval herring, Clupea harengus L., in the River Blackwater estuary, 1978-1980. J Fish Biol 24:613-622

Høie H, Folkvord A, Johannessen A (1999) Maternal, paternal and temperature effects on otolith size of young herring (Clupea harengus L.) larvae. J Exp Mar Biol Ecol 234: $167-184$

Hurley GV, Odense PH, O'Dor RK, Dawe EG (1984) Strontium labelling for verifying daily growth increments in the statolith of the short-finned squid (Illex illecebrosus). Can J Fish Aquat Sci 42:380-383

Iglesias J, Rodriguez-Ojea G (1997) The use of alizarin complexone for immersion marking of the otoliths of embryos and larvae of the turbot, Scophthalmus maximus (L.): dosage and treatment time. Fish Manage Ecol 4:405-417

Jean Y (1956) A study of spring and fall spawning herring (Clupea harengus L.) at Grande-Rivière, Bay of Chaleur, Québec. Report No. 49. Department of Fisheries, Québec

Jones C, Brothers EB (1987) Validation of the otolith increment aging technique for striped bass, Morone saxatilis, larvae reared under suboptimal conditions. Fish Bull 85: $171-178$

Lagardere F (1989) Influence of feeding conditions and temperature on the growth rate and otolith-increment deposition of larval Dover sole (Solea solea (L.)). Rapp P-v Réun Cons Int Explor Mer 191:390-399

Laroche JL, Richardson SL, Rosenberg AA (1982) Age and growth of a pleuronectid, Parophrys vetulus, during the pelagic larval period in Oregon coastal waters. Fish Bull 80:93-104

Lough RG, Pennington M, Bolz GR, Rosenberg AA (1982) Age and growth of larval Atlantic herring, Clupea harengus L., in the Gulf of Maine-Georges Bank region based on otolith growth increments. Fish Bull 80:187-199

Marshall SM, Nicholls AG, Orr AP (1937) On the growth and feeding of the larval and post-larval stages of the Clyde herring. J Mar Biol Assoc (UK) 22:245-267

McGurk MD (1983) Ring deposition in the otoliths of larval Pacific herring, Clupea harengus Pallasi. Fish Bull 82: 113-120

McGurk MD (1987) Age and growth of Pacific herring larvae based on length-frequency analysis and otolith ring number. Env Biol Fish 20:33-47

Moksness E (1992) Validation of daily increments in the otolith microstructure of Norwegian spring-spawned herring (Clupea harengus L.). J Mar Sci 49:231-235

Morales-Nin B (2000) Review of the growth regulation processes of otolith daily increment formation. Fish Res 46: $53-67$

Mugiya Y (1974) Calcium-45 behaviour at the level of the otolithic organs of rainbow trout. Bull Jpn Soc Sci Fish 40: 457-463

Mugiya Y, Watabe N, Yamada J, Dean JM, Dunkelberger DG, Shimizu M (1981) Diurnal rhythm in otolith formation in the goldfish, Carassius auratus. Comp Biochem Physiol 68A:659-662

Munk P, Christensen V (1990) Larval growth and drift pattern and the separation of herring spawning groups in the North Sea. J Fish Biol 37:135-148

Munk P, Christensen V, Paulsen H (1986) Studies of a larval herring (Clupea harengus L.) patch in the Buchan area. II. Growth, mortality and drift of larvae. Dana 6:11-24

Neilson JD (1992) Sources of error in otolith microstructure examination. Can J Fish Aquat Sci (Spec Publ) 117:115-125

Nichols JH, Read JW, Jones SR, Johnson MR (1985) Sampling a patch of herring larvae using an 'Argos' satellitetracked buoy as a marker. Report No. CM 1985/H:51. 
International Council for the Exploration of the Sea, Copenhagen

Payan P, Borelli G, Priouzeau F, Pontual Hd, Bœuf G, MayerGostan N (2002) Otolith growth in trout Onchorhynchus mykiss: supply of $\mathrm{Ca}^{2+}$ and $\mathrm{Sr}^{2+}$ to the saccular endolymph. J Exp Biol 205:2687-2695

Sameoto DD (1972) Distribution of herring (Clupea harengus) larvae along the southern coast of Nova Scotia with observations on their growth and condition factor. J Fish Res Bd Can 29:507-515

Schroder SL, Knudsen CM, Volk EC (1994) Marking salmon fry with strontium chloride solutions. Can J Fish Aquat Sci 52:1141-1149

Secor DH, Houde ED, Monteleone DM (1995) A mark-release experiment on larval striped bass Morone saxatilis in a Chesapeake Bay tributary. J Mar Sci 52:87-101

Shiao JC, Tzeng CS, Leu CL, Chen FC (1999) Enhancing the contrast and visibility of daily growth increments in fish otoliths etched by proteinase K buffer. J Fish Biol 54: 302-309

Szedlmayer S, Able KW (1992) Validation studies of daily increment formation for larval and juvenile summer flounder, Paralichthys dentatus. Can J Fish Aquat Sci 49:1856-1862

Editorial responsibility: Otto Kinne (Editor),

Oldendorf/Luhe, Germany
Tanaka K, Mugiya Y, Yamada J (1981) Effects of photoperiod and feeding on daily growth patterns in otoliths of juvenile Tilapia nilotica. Fish Bull US 79:459-466

Tibbo SN, Legaré HJE, Scattergood LW, Temple RF (1958) On the occurrence and distribution of larval herring (Clupea harengus L.) in the Bay of Fundy and the Gulf of Maine. J Fish Res Bd Can 15:1451-1469

Tytler P, Fox CJ, Folkvord A (2002) Glycoconjugates in the otolithic membrane of herring larvae: a possible framework for encoding the life history recorder in fishes. J Fish Biol 61:39-49

Waldron ME, Gerneke DA (1997) Comparison of two scanning electron microscope techniques for examining daily growth increments on fish otoliths. J Fish Biol 50: $450-454$

Wood CC, Burd AC (1976) Growth and mortality of herring larvae in the Central North Sea. Report No. CM 1976/H:8. International Council for the Exploration of the Sea, Copenhagen

Wright PJ, Talbot C, Thorpe JE (1992) Otolith calcification in Atlantic salmon parr, Salmo salar L. and its relation to photoperiod and calcium metabolism. J Fish Biol 40: $779-790$

Submitted: August 7, 2002; Accepted: July 29, 2003

Proofs received from author(s): December 2, 2003 